\title{
Integrasi Pembelajaran Matematika Berbasis ICARE dan Islam Pada Materi Pecahan
}

\author{
Elfi Rahmadhani ${ }^{1 *}$, Septia Wahyuni ${ }^{2}$ \\ 1,2Pendidikan Matematika, STAIN Gajah Putih Takengon Aceh Tengah, Aceh, Indonesia; \\ ${ }^{1 *}$ elfirahmadhani88@gmail.com
}

Info Artikel: Dikirim: 3 Desember 2019; Direvisi: 1 Februari 2010; Diterima: 27 Februari 2020 Cara sitasi: Rahmadhani, E., \& Wahyuni, S. (2020). Integrasi Pembelajaran Matematika Berbasis ICARE dan Islam Pada Materi Pecahan. JNPM (Jurnal Nasional Pendidikan Matematika), 4(1), 110-124.

\begin{abstract}
Abstrak. Tujuan penelitian ini untuk menghasilkan perangkat pembelajaran matematika berbasis Introduction, Connection, Application, Reflection dan Extension (ICARE) dan terintegrasi Islam berupa Rencana Pelaksanaan Pembelajaran (RPP), modul dan Lembar Aktivitas Siswa (LAS) yang valid, praktis dan efektif pada materi Pecahan. Penelitian ini merupakan penelitian pengembangan dengan menggunakan model ADDIE (Analysis, Design, Development, Implementation and Evaluation). Data pada penelitian ini didapatkan dari lembar validasi, lembar observasi keterlaksanaan pembelajaran, lembar observasi aktivitas siswa, angket respons siswa, angket respons guru dan hasil belajar siswa. Berdasarkan hasil pengolahan data diperoleh kesimpulan bahwa perangkat pembelajaran yang dikembangkan memenuhi kriteria valid dengan nilai 3,87, praktis dan efektif. Kriteria praktis yang didapatkan dari analisis data berikut: 1) keterlaksanaan pembelajaran dengan persentase ketuntasan 78 dan tergolong praktis, 2) aktivitas siswa yang mengalami peningkatan dari pertemuan pertama sampai pertemuan keempat yaitu 50\%, 72\%, 80\% dan 86\% dengan kategori sangat berhasil, 3) respons siswa dengan rata-rata skor adalah 3,04 dengan kategori praktis dan 4) respons guru dengan rata-rata skor adalah 3,1 dengan kategori praktis. Selanjutnya, kriteria efektif didapatkan dari hasil analisis pengolahan data hasil belajar siswa yang diketahui bahwa $89 \%$ siswa telah tuntas belajar menggunakan perangkat pembelajaran matematika berbasis ICARE dan terintegrasi Islam.
\end{abstract}

Kata Kunci: ICARE, Terintegrasi Islam, Pecahan.

Abstract. The purpose of this study was to produce mathematical learning tools based on Introduction, Connection, Application, Reflection, and Extension (ICARE) integrated on Islam in the form of lesson plans, modules, and student activity sheets that were valid, practical, and effective on Fractional material. This research was a development study using the ADDIE method (Analysis, Design, Development, Implementation, and Evaluation). The data in this study were obtained from the validation sheet, observation sheet of the implementation of learning, observation sheet of student activity, student response 
questionnaire, teacher response questionnaire, and student learning outcomes. Based on the results of data processing, it can be concluded that the development of learning tools fulfills valid criteria with a value of 3.87, practical and effective. Practical criteria obtained from the following data analysis: 1) the implementation of learning with the percentage of completeness $78 \%$ and classified as practical; 2) percentages of student activities that have increased from the first meeting until the fourth meeting were $50 \%, 72 \%, 80 \%$ and $86 \%$ with very successful categories, 3) student responses with an average score of 3.04 with practical categories and 4) teacher responses with an average score of 3.1 with practical categories. Furthermore, the effective criteria obtained from the analysis of student data processing results of learning that was known that $89 \%$ of students have finished learning to use mathematics learning tools based on ICARE and integrated on Islam.

Keywords: ICARE, Integrated Islam, Fraction.

\section{Pendahuluan}

Suatu proses pembelajaran dikatakan efektif dan efisien jika dalam prosesnya melibatkan siswa secara aktif baik dalam penemuan konsep maupun dalam memperkuat konsep materi. Kemajuan siswa dalam pembelajaran ditandai dengan tercapainya tujuan pembelajaran yaitu dengan hasil belajar yang baik. Karena hasil belajar merupakan salah satu aspek yang harus diperhatikan oleh guru. Ada beberapa faktor yang menyebabkan rendahnya hasil belajar siswa tersebut. Salah satunya seperti yang diungkapkan oleh Kurbaita, Zulkardi, \& Siroj (2013) faktor tersebut adalah kurangnya ketertarikan siswa dalam pembelajaran dan rumitnya bahan ajar yang digunakan yang menyebabkan siswa menjadi malas untuk belajar matematika. Dalam penelitian Khairoh, Rusilowati, \& Nurhayati (2014) juga mengatakan bahwa buku-buku bahkan bahan ajar yang beredar sekarang ini kurang menarik bagi siswa untuk membaca dan mempelajarinya, padahal matematika merupakan mata pelajaran yang diajarkan di setiap jenjang pendidikan.

Bahan ajar merupakan salah satu media pembelajaran yang dapat digunakan oleh guru dalam menyampaikan materi pelajaran. Seorang pendidik seharusnya memperhatikan kemampuan, usia dan tingkat psikologis siswanya, agar dapat membuat bahan ajar yang sesuai untuk mereka. Dengan adanya bahan ajar diharapkan siswa lebih memahami materi yang diberikan. Faktanya guru hanya menggunakan satu bahan ajar dalam menyampaikan materi. Materi yang ada pada bahan ajar yang digunakan tidak terstruktur dengan baik, bersifat abstrak, belum dikaitkan dengan dunia siswa dan belum terintegrasi dengan nilai-nilai Islam. Penggunaan bahan ajar seperti modul belum banyak digunakan. Modul pembelajaran merupakan seperangkat aktivitas yang bertujuan mempermudah siswa untuk mencapai tujuan pembelajaran (Wena, 2011). Modul memiliki sifat 
membantu dan mendorong pembacanya untuk mampu membelajarkan diri sendiri dan tidak bergantung pada media lainnya. Rahayu \& Sudarmin (2015) mengatakan bahwa suatu pembelajaran yang menggunakan modul dalam prosesnya sangat membantu guru dalam menyampaikan materi kepada siswa, modul juga membuat siswa lebih kreatif, mandiri sehingga mereka mudah menguasai kompetensi yang diberikan. Sejalan dengan itu, Yuniati \& Sari (2018) mengatakan bahwa keuntungan meggunakan modul dalam pembelajaran adalah dapat meningkatkan motivasi siswa, setelah evaluasi, guru dan siswa dapat mengetahui pada materi mana mereka belum berhasil, siswa mencapai hasil sesuai dengan kemampuannya, materi terbagi rata dalam satu semester dan pendidikan lebih berdaya guna.

Selain modul, Lembar Aktivitas Siswa (LAS) juga dapat digunakan oleh guru sebagai salah satu alternatif dalam menyampaikan materi. LAS berisikan sejumlah informasi serta instruksi yang ditujukan untuk mengarahkan siswa bertingkah laku sebagaimana yang diharapkan oleh guru. Melalui LAS siswa akan mampu mengingat suatu konsep lebih lama bahkan permanen karena konsep tersebut diperolehnya melalui keterlibatan mental atau berpikir mandiri, karena melalui lembar kerja terstruktur ini siswa dilatih untuk memahami berbagai macam konsep dasar matematika secara runtut dan logis, serta menjanjikan berbagai tipe soal secara tepat.

Namun pada kenyataannya, berdasarkan studi pendahuluan yang dilakukan di beberapa sekolah MI di Takengon diketahui bahwa masih banyak guru yang menggunakan bahan ajar yang siap pakai yang beredar dipasaran tanpa melihat apakah bahan ajar tersebut telah sesuai dengan kemampuan yang dimiliki oleh siswa. Hasil wawancara dengan siswa didapatkan bahwa bahan ajar yang digunakan oleh guru tersebut hanya berisikan materi dan soal yang harus mereka selesaikan tanpa melibatkan aktivitas penemuan konsep dan menanamkan nilai karakter didalamnya. Hal ini kemungkinan besar akan membuat tujuan pembelajaran tidak tercapai sesuai dengan yang diharapkan.

Sedangkan menurut penjelasan guru, penggunaan bahan ajar berupa Lembar Kerja Siswa (LKS) tersebut hanya digunakan sebagai alat bantu saja terutama dalam menguatkan konsep yag telah diterima oleh siswa melalui soal-soal. Namun berdasarkan analisis yang telah dilakukan oleh peneliti terhadap beberapa LKS yang digunakan oleh guru, terlihat bahwa penanaman konsep baik berupa proses mengkonstruksi konsep dan penemuan konsep baru yang melibatkan aktivitas siswa dan proses menanamkan nilai-nilai karakter yang dituntut dalam Kurikulum kurang 
maksimal diperoleh dalam LKS tersebut. Padahal, sudah merupakan tugas seorang guru untuk memberikan pelajaran yang tidak hanya membahas materi saja tetapi juga menanamkan nilai-nilai moral dan agama kepada siswa.

Sesuai dengan Permendiknas No. 20 Tahun 2016 tentang Standar Kompetensi Kelulusan (SKL) Pendidikan Dasar dan Menengah yang menyuratkan kebutuhan implementasi pembelajaran terintegrasi yang mencakup sikap, pengetahuan dan juga keterampilan. Menanamkan nilai agama tidak hanya harus dilakukan oleh guru PAI saja tetapi juga bisa dilakukan oleh semua guru, salah satunya adalah guru matematika. Namun kebanyakan guru sekolah atau madrasah mengaku kesulitan dalam mengintegrasikan matematika dengan Islam. Hal ini sejalan dengan pendapat Abdussakir \& Rosimanidar (2017) bahwa integrasi matematika dengan Islam memerlukan implementasi yang konkrit mulai dari praktek pembelajaran di sekolah sampai praktek didalam kehidupan. Untuk praktek di sekolah, guru dapat menggunakan modul dan LAS sebagai salah satu alternatif.

Pada saat ini, sudah seharusnya pembelajaran matematika diintegrasikan dengan pola ideologi Islam yang berlaku di masyarakat. Karena akhir-akhir ini Negara Barat telah mengintegrasikan pola pembelajaran mereka dengan sistem ideologinya. Misalnya seperti yang dikatakan Dr. Waqar Hussaini di Amerika sains-sosial dan kemanusiaan diajarkan dalam kerangka budaya Amerika. Sedangkan di Uni Soviet, pendidikan ilmiah diintegrasikan dengan disiplin-disiplin non-teknik dan seluruh siswanya harus mempelajari sejarah partai komunis Uni Soviet, etika Marxis, filsafat dan estetika Marxis-Leninis, dasar-dasar ateisme ilmiah, ekonomi politik dan dasar-dasar komunisme ilmiah. Hanya di Negara Islam, pengintegrasian pengajaran antara ideologi dengan disiplin sosial-teknik dan humanisme-teknik belum berlangsung.

Secara etimologi, menurut Esha (2009) kata integrasi berasal dari bahasa Inggris yaitu integrate yang berarti menggabungkan bagian-bagian yang terpisah dalam satu kesatuan. Sejalan dengan itu, dalam Kamus Besar Bahasa Indonesia, kata integrasi sebagai suatu usaha dan upaya untuk menjadikan dua hal atau lebih menjadi satu kesatuan yang tidak dapat terpisahkan. Integrasi secara umum dapat diartikan sebagai penyatuan/memadukan menjadi satu kesatuan yang utuh. Integrasi yang dimaksud bukan hanya menggabungkan pengetahuan umum dan agama atau memberikan bekal norma keagamaan saja, melainkan upaya 
mempertemukan cara pandang, cara pikir dan bertindak antara Barat dan Islam.

Sebenarnya dalam Al-Qur'an dan Hadits tidak ada membedakan antara ilmu agama dan ilmu umum, yang ada dalam Al-Qur'an adalah ilmu. Pembagian adanya ilmu agama dan ilmu umum merupakan hasil kesimpulan manusia yang mengidentifikasi ilmu berdasarkan objek dan kajiannya. Terdapat beberapa ayat Al-Qur'an dan Hadits Nabi yang menunjukkan tidak adanya perbedaan antara ilmu agama dan ilmu umum, salah satunya dijelaskan dalam Q.S Al-Qashah (28): 77 dimana setiap umat Islam dianjurkan agar meraih kebahagiaan yang seimbang antara dunia dan akhirat. Yang artinya:

"Dan carilah pada apa yang telah dianugerahkan Allah kepadamu (kebahagiaan) negeri akhirat dan janganlah kamu melupakan bahagiamu dari (kenikmatan) duniawi dan berbuat baiklah (kepada orang lain) sebagaimana Allah telah berbuat baik, kepadamu, dan janganlah kamu berbuat kerusakan di (muka) bumi. Sesungguhnya Allah tidak menyukai orang-orang yang berbuat kerusakan".

Integrasi matematika dan agama bukan proses islamisasi matematika. Integrasi ini bukan untuk menghasilkan matematika Islam, tetapi untuk membuat umat beragama lebih beragama melalui matematika. Lebih khususnya bukan islamisasi matematika, melainkan islamisasi manusia dan lingkungan sekitarnya dengan matematika (Abdussakir \& Rosimanidar, 2017). Integrasi matematika dan agama selain untuk menyeimbangkan sisi intelektual dan spiritual, bagi umat Islam juga berfungsi untuk mengenang kembali kejayaan Islam di abad pertengahan dalam pengembangan ilmu pengetahuan, sekaligus mengingat kembali matematikawan muslim seperti Al-Khawarizmi, Ibnu Haytham, Al-Biruni, Al-Khayyam dan Al-Tusi (Mohamed, 2001) yang merupakan sosok agamawan sekaligus matematikawan.

Beberapa strategi pembelajaran yang dapat dikaitkan dengan penanaman nilai-nilai Islam (Kumaryono \& Maharani, 2017) dan dapat dilakukan dalam pembelajaran matematika, yaitu: 1) selalu menyebut nama Allah, 2) penggunaan istilah, 3) ilustrasi visual, 4) aplikasi atau contoh-contoh, 5) menyisipkan ayat atau hadits yang relevan, 6) penelusuran sejarah, 7) jaringan topik dan 8) simbol ayat-ayat Kauniah (Ayat-ayat alam semesta). Nilai-nilai keislaman tersebut dapat dimasukkan ke dalam proses pembelajaran sehingga pembelajaran bernuansa Islam. Selain itu nilai Islam tersebut juga dapat diintegrasikan dalam materi pelajaran matematika, berupa materi maupun contoh soal. Setiap materi yang disampaikan, disisipkan ayat-ayat Al-Qur'an dan Hadits yang berhubungan dengan 
materi, sehingga selain siswa mendapatkan ilmu tentang matematika, mereka juga mampu mengaitkannya dengan nilai-nilai agama. Proses menanamkan nilai-nilai Islam tersebut dipadukan dengan pembelajaran ICARE. Pendekatan ICARE mencakup 5 hal yaitu: 1) Introduction, meliputi latar belakang, tujuan pembelajaran, garis besar materi, 2) Connection, meliputi pertanyaan tentang materi, 3) Application, meliputi permasalahan matematika yang diselesaikan secara berkelompok, 4) Reflection, meliputi permasalahan matematika yang diselesaikan secara individu dan 5) Extension, meliputi penguatan tentang materi. Kelima sintak ini sangat efektif digunakan dalam pengembangan perangkat pembelajaran sehingga menghasilkan perangkat yang relevan untuk dijadikan sebagai pedoman dalam kegiatan pembelajaran agar tujuan pembelajaran dapat tercapai dengan baik. Karena menurut Yanna, Masril, \& Yurnetti (2018) penggunaan bahan ajar salah satunya LAS berbasis ICARE dapat membantu meningkatkan kompetensi pengetahuan, sikap dan keterampilan siswa.

ICARE diperkenalkan oleh Decentralized Basic Education (DBE) yang dikembangkan oleh United Stated Agency International Development (USAID) tahun 2006. Menurut Maskur, Waluya, \& Rochmad (2012), ICARE meliputi lima langkah kunci untuk memastikan siswa menghubungkan pengalaman sebelumnya, memiliki kesempatan untuk menerapkan apa yang telah mereka pelajari dan mengaplikasikan pengetahuan dan keterampilan yang mereka dapatkan di akhir pelajaran. Langkah tersebut adalah Introduction, Connection, Application, Reflection dan Extension.

Pembelajaran dengan model pembelajaran ICARE menurut Wahyudin (2010) memiliki beberapa kelebihan, yaitu: 1) Pemetaan struktur isi yang seimbang antara teori dan praktek bagi guru dan siswa, 2) Memiliki pendekatan berbasis life skill, 3) Memungkinkan sekolah melakukan monitoring dan evaluasi yang terbuka kepada gurunya, 4) Memberikan peluang bagi sekolah untuk memformulasikan kembali struktur kurikulum yang ada dengan kebutuhan dan karakteristik siswa serta kondisi lingkungan yang ada, 5) Memberikan kesempatan kepada guru untuk melakukan apersepsi pada setiap pembelajaran yang akan dilakukan dengan mudah

Melihat banyaknya keuntungan dan pentingnya penggunaan bahan ajar dalam mendukung proses pembelajaran, maka penelitian ini bertujuan untuk mengembangkan perangkat pembelajaran matematika berbasis ICARE dan terintegrasi dengan nilai-nilai Islam. 


\section{Metode}

Jenis penelitian yang digunakan adalah penelitian pengembangan (Research and Development) dengan menggunakan model ADDIE (Analysis, Design, Development, Implementation and Evaluation). Pada tahap analysis yang dilakukan adalah 1) need assessment (analisis kebutuhan), 2) Analisis karakteristik siswa seperti usia, kemampuan akademik dan tingkat kedewasaan sebagai dasar dalam pengembangan perangkat pembelajaran dan 3) Analisis buku paket Matematika. Selajutnya pada tahap design yang dilakukan adalah: 1) Pemilihan format dan bagian modul dan LAS, 2) Penyusunan perangkat pembelajaran, yaitu modul dan LAS. Modul dan LAS disajikan dengan merujuk kepada komponen ICARE dan terintegrasi Islam.

Konsep pecahan disajikan dengan cara mengaitkan materi dengan konsep zakat dan warisan, terutama pada soal-soal latihan. Selain itu dalam modul dan LAS terdapat khazanah Islami yang berisikan Hadits atau ayat AlQur'an yang berhubungan dengan materi Pecahan. 3) Penyusunan Rencana Pelaksanaan Pembelajaran (RPP). RPP disusun merujuk kepada komponen ICARE (Introduction, Connection, Application, Reflection dan Extension). Selain itu, dalam kegiatan inti terutama pada proses penemuan konsep dan aplikasi dari konsep berupa soal-soal, dikaitkan dengan Islam terutama dengan konsep zakat dan warisan yang berhubungan dengan Pecahan.

Pada tahap development dikembangkan perangkat pembelajaran matematika berdasarkan validasi ahli dan revisi produk tahap I, kegiatan yang dilakukan pada tahap ini adalah: 1) pengembangan perangkat pembelajaran berdasarkan komponen ICARE dan terintegrasi Islam, 2) validasi ahli. Hal ini dilakukan dengan menguji validitas produk oleh 4 orang ahli yaitu dosen matematika, dosen media, dosen agama dan guru matematika, serta mendapatkan saran dan kritik dari validator terhadap produk yang dikembangkan dan 3) Revisi. Revisi dilakukan sebanyak dua kali. Revisi I produk dilakukan berdasarkan saran oleh para ahli. Jika produk dinyatakan valid maka perangkat siap untuk diujicobakan dalam pembelajaran. Perangkat yang telah divalidasi kemudian diujicobakan. Tahap Implementation dilakukan untuk menganalisis kepraktisan dan keefektifan perangkat yang dikembangkan. Pada tahap Evaluation dilakukan evaluasi terhadap kualitas produk hasil pengembangan berdasarkan angket, aktivitas dan pendapat ahli. Setelah dievaluasi, maka revisi akhir (II) produk akan menghasilkan produk akhir yang layak pakai. 
Sampel dalam penelitian pengembangan ini adalah siswa kelas V MIN 9 Takengon yang berjumlah 28 orang siswa. Uji coba ini dilakukan untuk melihat praktikalitas dan efektivitas perangkat berbasis ICARE dan terintegrasi Islam pada pembelajaran. Instrumen yang digunakan dalam penelitian adalah: a) lembar validasi, b) lembar observasi kegiatan pembelajaran, c) lembar observasi aktivitas siswa, d) angket respons siswa, e) angket respons guru, dan f) tes hasil belajar. Teknik analisis data yang digunakan dalam penelitian ini adalah analisis data secara kualitatif dan kuantitatif berdasarkan aspek kevalidan, kepraktisan dan keefektifan perangkat pembelajaran yang dikembangkan. Aspek kevalidan dilihat dari validasi perangkat yang diperoleh dari saran dan komentar validator. Aspek kepraktisan diperoleh dari keterlaksanaan RPP, aktivitas siswa, respons guru dan respons siswa terhadap perangkat yang dikembangkan. Sedangkan aspek keefektifan dilihat dari hasil belajar siswa setelah digunakan perangkat pembelajaran berbasis ICARE dan terintegrasi Islam tersebut.

Tahapan dalam pembelajaran ICARE mengikuti langkah-langkah Yumiati \& Wahyuningrum (2015) sebagai berikut: Introduction. Pada tahap ini dijelaskan garis besar isi materi pelajaran secara keseluruhan, tujuan yang akan dicapai, materi prasyarat, waktu yang diperlukan, kegiatan dan evaluasi yang akan dilakukan, serta bahan bacaan yang diperlukan. Pada tahap ini dimaksudkan juga untuk mengetahui sejauh mana pemahaman dan minat siswa dalam mengikuti pembelajaran yang akan diberikan.

Langkah kedua adalah Connection. Pada tahap ini diperkenalkan fakta-fakta, konsep, prinsip, dan proses yang berkaitan dengan materi yang akan dipelajari. Dalam kegiatan ini memberi kesempatan siswa untuk menemukan fakta-fakta, konsep, prinsip sendiri. Ada 4 langkah yang disarankan Pastor (Wahyudin, 2010) pada tahap ini, yaitu: 1) membagi materi ke dalam sub-sub topik untuk memudahkan siswa memahami informasi baru, 2) menghubungkan informasi kepada tugas-tugas yang berkaitan dengan dunia nyata dan pengetahuan sebelumnya, 3) mMemfasilitasi siswa dengan informasi secara bertahap dan berkesinambungan sehingga merupakan rangkaian belajar yang bermakna dan 4) Menyajikan bahan yang akan diberikan secara lebih menyenangkan dengan berbagai pendekatan dan penggunaan media.

Langkah ketiga adalah Application. Tahap ini memberikan tantangan dan kegiatan yang memungkinkan siswa untuk menerapkan pengetahuan yang mereka dapatkan pada tahap II dengan memberikan masalah-masalah yang berkaitan dengan dunia nyata. Kegiatan simulasi, permainan atau menebak 
sangat baik dilakukan pada tahap ini. Kegiatan ini yang dapat juga dilakukan pada tahap ini adalah meminta siswa mencari situs lain yang relevan.

Langkah keempat adalah Reflection. Pada tahap ini siswa diminta untuk merenungkan tentang apa yang telah mereka pelajari, apa yang mereka peroleh dan pengalaman yang didapatkan dari tahap connect sampai aplly. Bantulah siswa mengorganisasikan pikiran mereka tentang apa yang baru saja mereka pelajari dengan memberikan kesempatan kepada mereka untuk mendiskusikan dan memperluas informasi. Hal ini dapat dilakukan dengan beberapa cara. Mendiskusikan tentang pembelajaran, meminta siswa membuat peta konsep, merepresentasikan secara visual hubungan antar konsep. Peta konsep sangat berguna bagi siswa untuk membantu memperluas informasi baru.

Langkah terakhir adalah Extansion. Pada tahap ini memberi kesempatan siswa memperluas pengetahuan yang telah diperoleh dengan memberi tantangan masalah yang lebih luas. Ada dua kegiatan utama pada tahap akhir ini, yaitu: 1) memberikan kegiatan pengayaan dan remediasi dan 2) memberikan evaluasi terhadap penguasaan materi siswa dan evaluasi terhadap bahan ajar atau desain pembelajaran.

\section{Hasil dan Pembahasan}

Hasil wawancara yang telah dilakukan kepada guru dan siswa diketahui bahwasanya: siswa SD/MI membutuhkan suatu perangkat pembelajaran matematika yang dapat membantu mereka memahami materi matematika secara mudah, siswa jarang dilibatkan secara aktif dalam proses pembelajaran, dan siswa kurang diperkenalkan dengan keterkaitan antara matematika dan agama Islam. Pada tahap design dan development dilakukan pengembangan perangkat pembelajaran berdasarkan komponen ICARE dan terintegrasi Islam yang kemudian dilakukan validasi oleh ahli yaitu dosen matematika, dosen media, dosen agama dan guru matematika. Validator tidak hanya menguji validitas dari perangkat pembelajaran yang dikembangkan saja, tetapi juga semua instrumen yang digunakan dalam mengembangkan perangkat tersebut. Kevalidan produk ditentukan dengan menghitung rata-rata nilai aspek dari setiap validator dan melihat kriteria validitasnya. Berdasarkan hasil pengolahan data didapatkan bahwa perangkat yang dikembangkan memiliki nilai $x=3,87$ dengan kriteria valid. 
Hal ini dilihat dari rata-rata validasi ahli tentang materi yaitu kelayakan isi, kebahasaan yang telah sesuai dengan tuntutan kurikulum, teknik penyajian dan kegrafikan dari perangkat yang dikembangkan juga telah sesuai dengan tingkat perkembangan siswa, serta pendapat validator ahli media dan agama tentang desain perangkat tersebut yang telah memenuhi kriteria valid. Maskur, Waluya, \& Rochmad (2012) juga mengatakan bahwa perangkat pembelajaran dapat digunakan jika memenuhi kriteria kevalidan, kepraktisan dan keefektifan. Dimana perangkat tersebut dikatakan valid karena 1) perangkat yang dikembangkan telah sesuai dengan tuntutan kurikulum, 2) perangkat yang dikembangkan telah sesuai dengan tahapan ICARE dan terintegrasi Islam, dan 3) perangkat yang dikembangkan telah sesuai dengan tingkat perkembangan siswa dan berfokus kepada siswa. Pendapat ini didukung oleh pendapat Dwijayani (2017) yang mengatakan bahwa perangkat pembelajaran dikatakan valid karena 1) telah sesuai dengan tuntutan dalam kurikulum pembelajaran, 2) mampu memotivasi siswa dalam pembelajan dan 3) pembelajaran berfokus kepada siswa.

Saran dan komentar dari validator dijadikan masukan untuk memperbaiki perangkat pembelajaran yang dikembangkan. Dosen agama menyarankan untuk menambah soal yang dikaitkan dengan nilai agamanya seperti menambahkan soal tentang pembagian zakat dan warisan pada materi operasi perkalian pecahan. Sedangkan dosen media menyarankan untuk memperbaiki ukuran emotikon dan gambar yang digunakan sebagai ilustrasi agar selaras dengan besar tulisan yang digunakan. Setelah melakukan revisi tahap 1 terhadap perangkat yang dikembangkan dan diperoleh bahwa RPP, modul dan LAS yang dikembangkan valid, maka langkah selanjutnya adalah implementation yaitu melakukan ujicoba lapangan untuk mengetahui kepraktisan dan keefektifan perangkat pembelajaran matematika yang dikembangkan. Uji coba lapangan dilakukan dengan melibatkan 28 orang siswa kelas V MIN 9 Takengon dengan menerapkan pembelajaran berbasis ICARE yang terintegrasi Islam menggunakan RPP, modul dan LKS yang telah dikembangkan. Pembelajaran dilakukan dalam empat kali pertemuan dengan materi pembelajaran adalah Pecahan. Untuk kriteria kepraktisan, berdasarkan hasil observasi keterlaksanaan pembelajaran menggunakan perangkat yang dikembangkan tergolong praktis dengan persentase ketuntasan $\mathrm{n}=78$ yang berada pada rentang $61 \leq n<81$. Selain itu aktivitas siswa selama mengikuti pembelajaran dengan menggunakan perangkat pembelajaran yang dikembangkan juga dianalisis. Hasil analisis aktivitas siswa dapat dilihat pada tabel 1 di bawah ini: 
Tabel 1. Hasil Analisis Aktivitas Belajar Siswa

\begin{tabular}{cccc}
\hline Pertemuan ke- & Persentase $(\%)$ & Tingkat Keberhasilan & Kriteria \\
\hline 1 & 50 & Kurang berhasil & Sedikit \\
2 & 72 & Berhasil & Banyak \\
3 & 80 & Sangat berhasil & Banyak Sekali \\
4 & 86 & Sangat berhasil & Banyak Sekali \\
\hline
\end{tabular}

Berdasarkan tabel 1, diketahui bahwa pada pertemuan pertama masih sedikit siswa yang aktif dalam pembelajaran yaitu sekitar $50 \%$ siswa. Hal ini disebabkan karena siswa belum terbiasa dengan model dan aktivitas pembelajaran yang diberikan. Namun pada pertemuan kedua sudah banyak siswa yang aktif dalam pembelajaran yaitu $72 \%$ siswa, bahkan pada pertemuan ketiga dan keempat dapat dikategorikan sangat berhasil penggunaan perangkat pembelajaran yang diberikan, $80-86 \%$ siswa aktif dalam pembelajaran. Hal ini dikarenakan siswa mulai terbiasa dengan model dan aktivitas pembelajaran yang diberikan.

Setelah memberikan pembelajaran dengan menggunakan perangkat yang dikembangkan, maka pada pertemuan terakhir siswa diberikan tes untuk mengukur kemampuan mereka setelah mengikuti pembelajaran yang menggunakan perangkat pembelajaran matematika berbasis ICARE dan terintegrasi Islam. Hasil analisis hasil belajar siswa dapat dilihat pada tabel 2 berikut ini:

Tabel 2. Hasil Analisis Data Hasil Belajar Siswa

\begin{tabular}{ccccc}
\hline No. & Nilai & Jumlah siswa & Persentase $(\%)$ & Keterangan \\
\hline 1 & $\geq 70$ & 25 & 89 & Tuntas \\
2 & $<70$ & 3 & 11 & Tidak tuntas \\
& Jumlah & 28 & & \\
\hline
\end{tabular}

Berdasarkan hasil analisis pengolahan data hasil belajar siswa pada tabel $2 \mathrm{di}$ atas, diketahui bahwa $89 \%$ siswa tuntas belajar dan $11 \%$ siswa tidak tuntas dalam pembelajaran menggunakan perangkat pembelajaran matematika berbasis ICARE dan terintegrasi Islam yang dikembangkan. Hal ini menunjukkan bahwa perangkat pembelajaran yang dikembangkan memenuhi kriteria efektif dengan $89 \%$ siswa tuntas dalam pembelajaran. Perangkat pembelajaran yang dikembangkan dikatakan efektif karena mampu memberikan kesempatan kepada siswa untuk menemukan sendiri konsep dari materi yang dipelajari dan dikaitkan dengan kehidupan seharihari mereka. Hal ini sejalan dengan pendapat Asri, Rusdiana, \& Feranie (2017) yang mengatakan bahwa pendekatan pembelajaran ICARE memberikan kesempatan bagi guru untuk melibatkan siswa dalam setiap 
tahapan pembelajaran pada pendekatan tersebut sehingga mereka dapat memaknai setiap proses penemuan konsep. Menurut Mahdian, Almubarak, \& Hikmah (2019) pembelajaran dengan menggunakan pendekatan ICARE dapat meningkatkan hasil belajar siswa, karena setiap fase dari pendekatan ini dapat menggali pengetahuan siswa sesuai dengan teori konstruktivisme mulai dari tahap Introduction (pengenalan), Connection (menghubungkan), Application (mengaplikasikan), Reflection (refleksi) dan Extension (menerapkan).

Selain tes, pada pertemuan terakhir siswa dan guru diberikan angket untuk melihat respons mereka terhadap perangkat yang telah dikembangkan. Hal ini dilakukan untuk mengukur tingkat praktikalitas dari perangkat tersebut selain dengan melihat ketercapaian pembelajaran dan aktivitas siswa. Berdasarkan hasil analisis respons siswa dan respons guru yang diperoleh dari angket yang diberikan diketahui bahwa rata-rata skor respons siswa adalah 3,04 dengan kategori praktis dan rata-rata skor respons guru adalah 3,1 dengan kategori praktis. Perangkat pembelajaran matematika berbasis ICARE dan terintegrasi Islam tersebut dikatakan praktis karena mampu memberikan manfaat kepada guru dan siswa dalam pembelajaran. Menurut Dwijayani (2017) hal ini karena 1) perangkat yang dikembangkan dapat menumbuhkan minat dan antusias siswa dalam pembelajaran, 2) RPP yang jelas dan detail mempermudah guru dalam proses pembelajaran, dan 3) siswa menjadi lebih tahu keterkaitan matematika dengan dunia sekitar mereka.

Perangkat pembelajaran yang dikembangkan selain berbasis ICARE juga terintegrasi Islam. Dimana perangkat pembelajaran yang dikembangkan ini memuat nilai-nilai Islam didalamnya dengan mengaitkan setiap konsep dan soal-soal dengan nilai Islam yang berhubungan dengan materi yang diajarkan. Menurut Khoiriyah \& Rizki (2017) bahan ajar yang diintegrasikan dengan nilai-nilai Islam sangat cocok dan baik untuk membantu proses pembelajaran, hal ini disebabkan karena siswa dapat mengambil hikmah dari apa yang mereka pelajari. Selain mendapatkan materi matematika di sekolah, siswa juga dibekali dengan nilai-nilai Islam yang terkandung di dalam materi yang mereka pelajari. Hal ini sesuai dengan pendapat Rizki \& Widiyanti (2017) yang mengatakan bahwa kelebihan bahan ajar matematika berbasis nilai-nilai Islam adalah memiliki kandungan nilai-nilai Islam dalam materinya.

Pengintegrasian nilai Islam dalam RPP, modul dan LAS pada materi Pecahan ini bukan bertujuan untuk mengislamkan materi tersebut, namun 
mengaitkan materi yang diajarkan dengan nilai-nilai Islam yang terkandung dan terkait dalam materi yang dipelajari. Sesuai dengan pendapat Muspiroh (2014) bahwa pengintegrasian nilai Islam dengan suatu ilmu merupakan penyatuan antara ilmu dan agama dengan tujuan agar siswa tidak hanya menguasai ilmu pengetahuan saja tetapi juga semakin dekat dengan penciptanya.

Integrasi nilai Islam pada materi Pecahan ini misalnya adalah dengan menggunakan soal-soal yang terkait dengan nilai Islam seperti: pembagian harta warisan (Surat An-Nisa': 11-13 dan 176) (Salafudin, 2015), pembagian malam berhubungan dengan bangun untuk melaksanakan shalat (Surat AlMuzzammil: 20), hadist tentang keutamaan bagi orang yag khusyu' dalam shalat (HR Abu Daud, Sanad Hasan), hadist tentang keutamaan waktu shalat malam (HR Bukhari no. 1079), hadist tentang zakat mal (HR Abu Daud no. 1573), hadist tentang keutamaan menikah (HR Al Baihaqi dalam Syu'abul Iman, dishahihkan oleh Syaikh Al Albani dalam As Silsilah Ash Shahihah no. 625), dan hadist tentang keutamaan Q.S Al Ikhlas (HR Muslim) (Pendra, 2012; Kurniati, 2015).

Hasil pengembangan perangkat pembelajaran tersebut dapat dilihat pada Gambar 1.
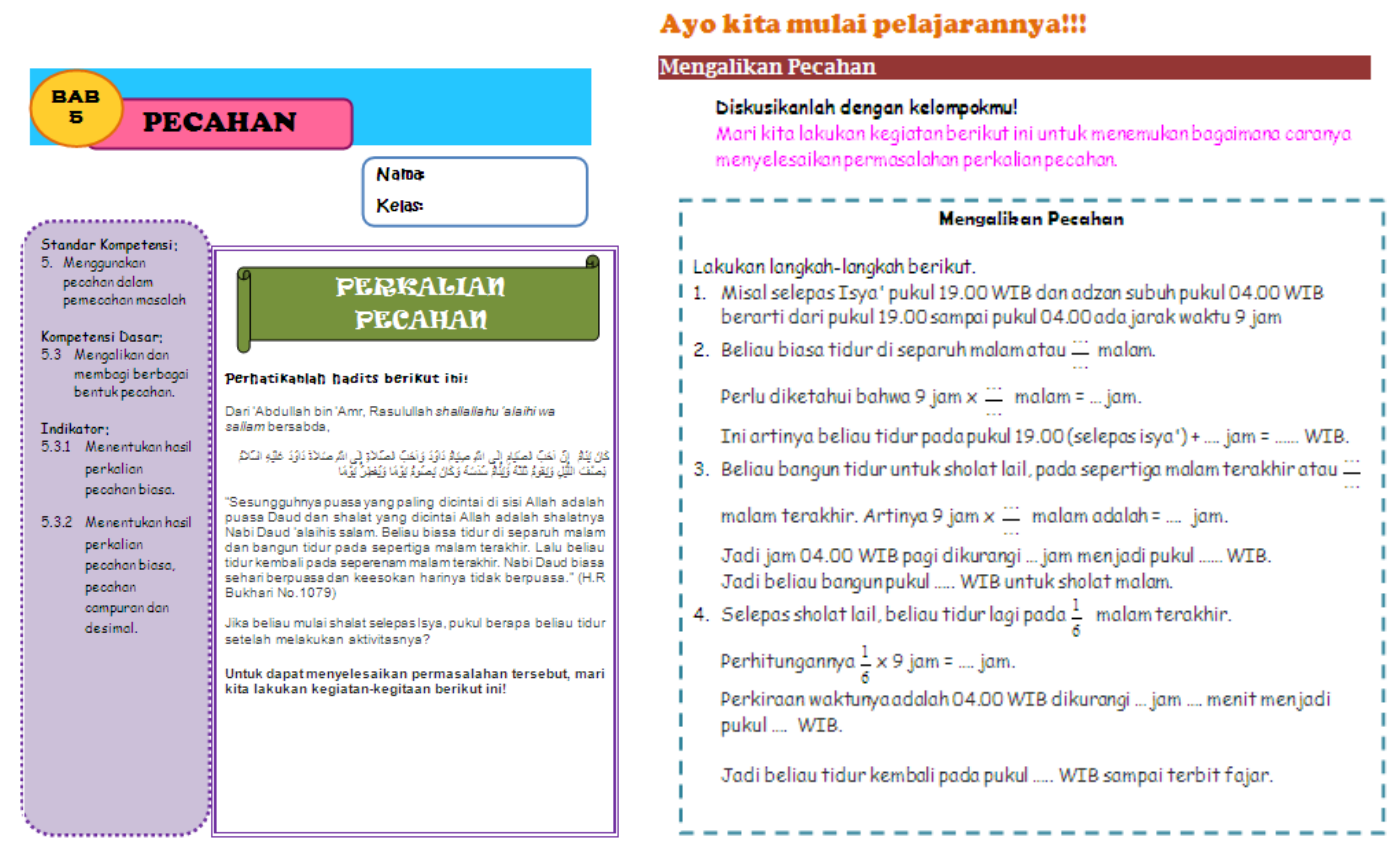

Gambar 1. LAS berbasis ICARE dan terintegrasi Islam

Perangkat pembelajaran matematika berbasis ICARE dan terintegrasi Islam yang dikembangkan dievaluasi untuk menghasilkan suatu produk akhir 
yang layak pakai. Berdasarkan hasil pengolahan data, diketahui bahwa perangkat pembelajaran matematika berbasis ICARE dan terintegrasi Islam berupa RPP, modul dan LAS memenuhi kriteria valid, praktis dan efektif.

\section{Simpulan}

Berdasarkan hasil temuan dan pembahasan yang telah dikemukakan sebelumnya, diperoleh kesimpulan bahwa perangkat pembelajaran matematika berbasis ICARE dan terintegrasi Islam yang dikembangkan pada materi Pecahan memenuhi kriteria valid, praktis dan efektif. Perangkat yang dikembangkan pada penelitian ini adalah RPP, modul dan LAS. Hasil pengolahan data validasi yang diperoleh dari validator diperoleh kriteria valid dengan beberapa perubahan pada LAS yang dikembangkan. Dosen agama menyarankan untuk menambah soal yang dikaitkan dengan nilai agamanya seperti menambahkan soal tentang pembagian zakat dan warisan pada materi operasi perkalian pecahan. Sedangkan dosen media menyarankan untuk memperbaiki ukuran emoticon dan gambar yang digunakan sebagai ilustrasi agar selaras dengan besar tulisan yang digunakan. Kriteria praktis didapatkan dari analisis data 1) keterlaksanaan pembelajaran yang tergolong praktis, 2) aktivitas siswa yang mengalami peningkatan dari pertemuan pertama sampai pertemuan keempat dengan kategori sangat berhasil, 3) respons siswa dari angket dengan kategori praktis dan 4) respons guru dengan kategori praktis. Untuk kriteria efektif didapatkan dari hasil analisis pengolahan data hasil belajar siswa yang diketahui bahwa $89 \%$ siswa tuntas belajar dan $11 \%$ siswa tidak tuntas dalam pembelajaran menggunakan perangkat pembelajaran matematika berbasis ICARE dan terintegrasi Islam yang dikembangkan.

\section{Daftar Pustaka}

Abdussakir, \& Rosimanidar. (2017). Model Integrasi Matematika dan Al-Quran serta Praktik Pembelajarannya. Prosiding Seminar Nasional Integrasi Matematika didalam Al-Quran, 116.

Asri, Y. N., Rusdiana, D., \& Feranie, S. (2017). ICARE Model Integrated with Science Magic to Improvement of Students' Cognitive Competence In Heat and Temperature Subject. Altlantis Press 1st International Conference of Mathematics and Science Education (ICMSEd 2016), 57(ICMSEd 2016), 137-139.

Dwijayani, N. M. (2017). Pengembangan Media Pembelajaran ICARE. Jurnal KREANO, 8(2), 126-132.

Esha, M. I. (2009). Institutional Transformation. Malang: UIN Maliki Press.

Khairoh, L., Rusilowati, A., \& Nurhayati, S. (2014). Pengembangan Buku Cerita IPA Terpadu Bermuatan Pendidikan Karakter Peduli Lingkungan Pada Tema Pencemaran Lingkungan. Unnes Science Education Journal, 3(2), 519-527.

Khoiriyah, U., \& Rizki, S. (2017). Pengembangan Bahan Ajar Himpunan Matematika yang Dikaitkan dengan Nilai-Nilai Islam. AKSIOMA: Jurnal Program Studi Pendidikan 
Matematika, 6(3), 315-322.

Kumaryono, I., \& Maharani, H. R. (2017). Penerapan Pembelajaran Berkarakter Islami Pada Program PPL Mahasiswa Pendidikan Matematika Unissula Semarang. Suska Journal of Mathematics Education, 3(2), 119-129.

Kurbaita, Zulkardi, \& Siroj. (2013). Pengembangan Buku Ajar Matematika Tematik Integratif Materi Pengukuran Berat Benda untuk Kelas I SD. Kreano: Jurnal Matematika KreatifInovatif, 4(1), 1-10.

Kurniati, A. (2015). Mengenalkan Matematika Terintegrasi Islam Kepada Anak Sejak Dini. Suska Journal of Mathematics Education, 1(1), 1-8.

Mahdian, M., Almubarak, A., \& Hikmah, N. (2019). Implementasi Model Pembelajaran ICARE (Introduction-Connect-Apply-Reflect-Extend) Terhadap Keterampilan Proses Sains Pada Materi Larutan Elektrolit Dan Non Elektrolit. Jurnal Penelitian Pendidikan IPA (JPPIPA), 5(1), 92-97.

Maskur, A., Waluya, S. B., \& Rochmad. (2012). Pembelajaran Matematika dengan Strategi ICARE Beracuan Konstruktivisme Untuk Meningkatkan Kemampuan Berpikir Kreatif Materi Dimensi Tiga. Journal of Primary Education, 1(2), 85-90.

Mohamed, M. (2001). Matematikawan Muslim Terkemuka. Diterjemahkan oleh Thamir Abdul Hafedh Al-Hamdany. Jakarta: Salemba Teknika.

Muspiroh, N. (2014). Integrasi Nilai-Nilai Islam dalam Pembelajaran IPA di Sekolah. Quality: Journal of Empirical Research in Islamic Education, 2(1), 168-188.

Pendra, T. (2012). Klasifikasi Ayat-Ayat Al-Qur'an yang Memuat Konsep Matematika. Universitas Islam Negeri Maulana Malik Ibrahim Malang.

Kemendikbud. 2016. Permendiknas No. 23 Tahun 2006 tentang Standar Kompetensi Kelulusan (SKL). Jakarta: Kemendikbud.

Rahayu, W. E., \& Sudarmin. (2015). Pengembangan Modul IPA Terpadu Berbasis Etnosains Tema Energi Dalam Kehidupan untuk Menanamkan Jiwa Konservasi Siswa. USEJ Unnes Science Education Journal, 4(2), 919-926.

Rizki, S., \& Widiyanti, R. (2017). Pengembangan Bahan Ajar Logika Matematika Berbasis Nilai-Nilai Islam. Seminar Nasional Matematika UHAMKA, 1, 84-89. UHAMKA.

Salafudin. (2015). Pembelajaran Matematika Yang Bermuatan Nilai Islam. Jurnal Penelitian, 12(2), 223-243.

Wahyudin, D. (2010). Model Pembelajaran ICARE Pada Kurikulum Mata Pelajaran TIK di SMP. Jurnal Penelitian Pendidikan, 11(1), 23-33.

Wena, M. (2011). Strategi Pembelajaran Inovatif Kontemporer. Jakarta: Bumi Aksara.

Yanna, F., Masril, \& Yurnetti. (2018). LKPD Berbasis Model Pembelajaran ICARE Kelas VIII SMPN 31 Padang. Pillar of Physics Education, 11(1), 145-152.

Yumiati, Y., \& Wahyuningrum, E. (2015). Pembelajaran ICARE (Introduction, Connect, Apply, Reflect, Extend) dalam Tutorial Online Untuk Meningkatkan Kemampuan Pemecahan Masalah Matematis Mahasiswa UT. Infinity Journal, 4(2), 182-189.

Yuniati, S., \& Sari, A. (2018). Pengembangan Modul Matematika Terintegrasi Nilai-Nilai Keislaman Melalui Pendekatan Realistic Mathematics Education (RME) di Propinsi Riau. Jurnal Analisa, 4(1), 1-9. 